\title{
Novel catalytic fluorescence method for speciative determination of chromium in environmental samples
}

\author{
Sunil Adurty ${ }^{*}$ and Jagadeeswara Rao Sabbu
}

\begin{abstract}
Background: Thiourea derivatives act as promising chemosensors for sensing transition metal ions. 1-(2-hydroxyphenyl) thiourea (HPTU) is one such chromophore that has potential for metal ion sensing. The current investigation reports the sensing of chromium species using transition metal-oxo-based reaction of 1,2-hydroxyphenylthiourea.

Methods: The catalytic effect of chromium (III) and chromium (VI) on the oxidation of HPTU was studied. The reaction was followed spectrofluorimetrically by measuring the fluorescence intensities of the reaction product at $\lambda_{\mathrm{ex}}=416$ and $\lambda_{\mathrm{em}}=520 \mathrm{~nm}$, respectively.

Results: Under the optimum analytical conditions, HPTU acts as a chromogenic sensor for the detection of chromium species in nano-gram levels with a determination range of 0.3 to $250 \mathrm{ng} / \mathrm{mL}$.

Conclusions: The methods are fairly sensitive, and the role of activators and sensitizers in enhancing the catalysis was studied. Interference due to various cations and anions in the experiment was investigated. The proposed method was applied to environmental samples for the analysis of chromium content.
\end{abstract}

Keywords: 1-(2-hydroxyphenyl) thiourea; Chromium; Speciative determination; Catalytic fluorescence

\section{Background}

The toxicological and biological characteristics of many transition metals like chromium are related to their chemical forms. A great interest in chromium speciation originates from applications of this metal in various industrial activities such as tanning of leather, electroplating, pigment production and wood preservation. Owing to these industrial processes, large amounts of chromium compounds discharge into the environment, which can affect biology and ecology of the environment. Therefore, speciation analysis of chromium is of great importance to assess pollution levels. Chromium mainly exist in two oxidation states, i.e. $\mathrm{Cr}(\mathrm{III})$ and $\mathrm{Cr}(\mathrm{VI})$. $\mathrm{Cr}(\mathrm{III})$ appears to be one of the essential elements for the proper functioning of living organisms, effective in the maintenance of normal glucose, cholesterol and fatty acid metabolism, while water soluble $\mathrm{Cr}(\mathrm{VI})$ is toxic to human and living organisms and

\footnotetext{
* Correspondence: asunil@sssihl.edu.in

Department of Chemistry, Sri Sathya Sai Institute of Higher Learning

(Deemed to be university), Prasanthi Nilayam-515134, Puttaparthi, Anantapur District, Andhra Pradesh, India
}

was found to be carcinogenic. Due to the different toxicities of $\mathrm{Cr}(\mathrm{III})$ and $\mathrm{Cr}(\mathrm{VI})$, and due to their association in many sample matrices, it is necessary to develop methods where both species can be determined simultaneously (Kotas and Stasicka 2000).

In the past years, various analytical techniques such as atomic absorption spectrometry (AAS) (Karosi et al. 2006; Ren et al. 2007) spectrophotometry (Wu et al. 2007), stripping voltammetry (SV) (Grabarczyk et al. 2006), inductively coupled plasma-mass spectrometry (ICP-MS) (Sun et al. 2006), inductively coupled plasma-optical emission spectrometry (ICPOES) (Schramel et al. 1992), and high performance liquid chromatography (HPLC) (Padarauskas and Naujalis 1998) have been successfully used to determine chromium in various samples. An extensive coverage of the available methods for chromium determination was put forth by Gomez and Callao, including the various types of sample matrices selected for the determination (Gomez and Callao 2006). Reagents such as bis-[2-hydroxy-1-naphthaldehyde] thiourea (Kiran et al. 2008), quercetin (Hosseini and Belador, 2009), chromotropic

\section{实}

(c) 2015 Adurty and Sabbu; licensee Springer. This is an open access article distributed under the terms of the Creative Commons Attribution License (http://creativecommons.org/licenses/by/2.0), which permits unrestricted use, distribution, and reproduction in any medium, provided the original work is properly credited. 
acid (CA) (Themelis et al. 2006), bis (salicylaldehyde) orthophenylenediamine (BSOPD) (Arancibia et al. 2012 and Soomro et al. 2011), etc. have been used. Methods such as solidified floating organic drop microextraction (SFODME) in combination with graphite furnace atomic absorption spectrometry (GFAAS) (Moghadam et al. 2011), cloud point extraction (CPE) using diethyldithiocarbamate (DDTC) as the chelating agent (Yildiz et al. 2011), solid phase extraction procedure using ICP-MS (Guerrero et al. 2012), fluorescence method using tetraphenylphosphonium bromide $\left(\mathrm{TPP}^{+} \cdot \mathrm{Br}^{-}\right)$(El-Shahawi et al. 2011), EPA methods 3060A and 3052 (Martone et al. 2013), a disposable dual screen-printed electrode method using batch and flow analysis (Sánchez-Moreno et al. 2010), p-aminoacetophenone and phloroglucinol (Parmar et al. 2010), ultrasoundassisted cloud point extraction (UACPE) (Hashemi and Daryanavard 2012), electrospray ionization mass spectrometry using CYDTA (Hotta et al. 2012), HPLC and preconcentration by CPE with 1-(2-thiazolylazo)-2-naphthol (TAN) as the chelating agent (Wang et al. 2010), ytterbium (III) hydroxide (Duran et al. 2009), mixed-micelle cloud point extraction using electrothermal atomic absorption spectrometry (ET-AAS) (Ezoddin et al. 2010), room temperature ionic liquids (RTILs) for hollow fiber liquid phase microextraction (HF-LPME) combined with flame atomic absorption spectrometry (FAAS), etc., have been developed (Zeng et al. 2012).
It is evident from the literature that hexavalent chromium compounds are 10 to 100 times more toxic than trivalent chromium compounds when administered orally. The World Health Organization (WHO) and the European Community Directive (ECD) for drinking water has set the limit of total chromium not exceeding $50 \mu \mathrm{g} \mathrm{L}^{-1}$, while the maximum concentration criterion for $\mathrm{Cr}(\mathrm{VI})$ in freshwater is $16 \mu \mathrm{g} \mathrm{L}{ }^{-1}$, sea water contains between 0.1 and $0.5 \mu \mathrm{g} \mathrm{L}^{-1}$ and unpolluted river water from 0.3 to $0.6 \mu \mathrm{g} \mathrm{L}^{-1}$. Since the concentration of chromium, mainly $\mathrm{Cr}(\mathrm{VI})$, is very low in many natural waters, a highly sensitive method is required for its speciation (Arancibia et al. 2012). Innumerable techniques and methods were reported for chromium speciation using highly sophisticated equipment. Among the plethora of the methods, photometric and fluorometric methods are comparatively simple and relatively sensitive. Hence, speciative determination of chromium by parameter selective approach using a novel thiourea derivative was proposed. This paper is an extension of the work carried out and formerly reported by the authors (Sunil and Rao 2015). Many analytical methods reported for chromium determination are based on the Beer's law and the metal ligand complexation studies by addition of oxidizing agents like hydrogen peroxide. But, the reaction utilized in the current study is a unique catalytic reaction in itself because the reagent synthesis is very

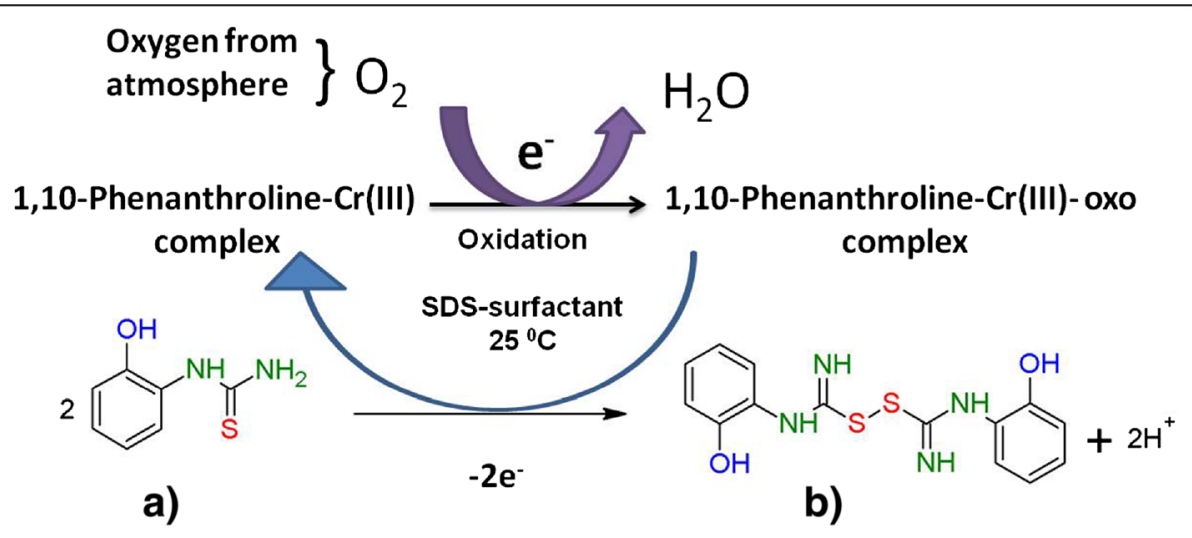

1-(2-hydroxyphenyl)thiourea

1-hydroxy-2-[(\{[N-(2-hydroxyphenyl)carbamimi doyl]disulfanyl\}carbonoimidoyl)amino]benzene

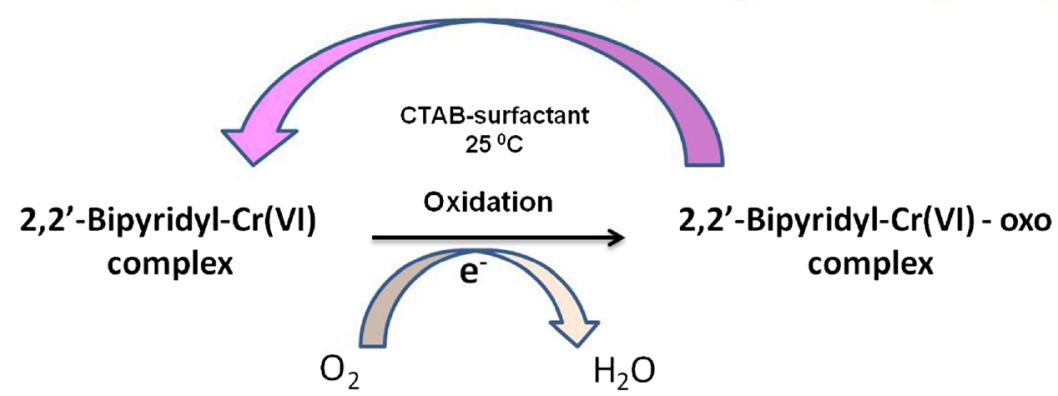

Scheme 1 The proposed mechanism for the process of catalytic effect of chromium species on HPTU. 

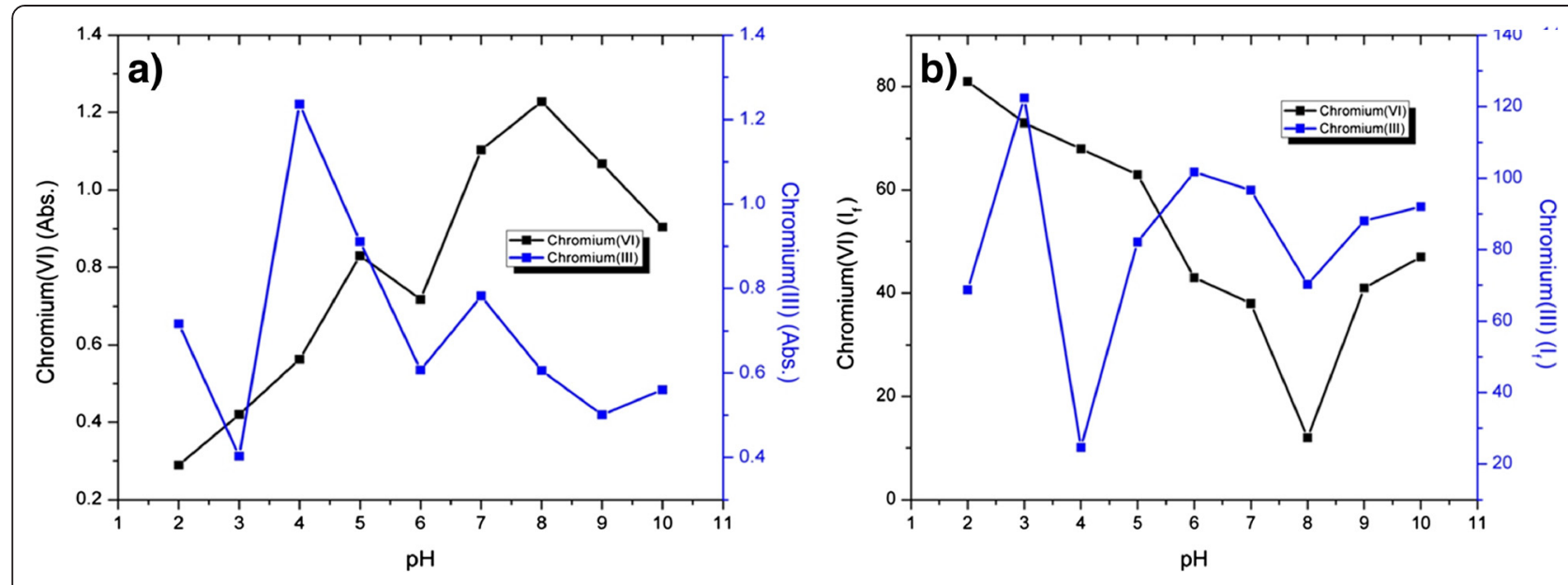

Figure 1 Effect of pH on photometric absorbance and fluorometric quenching studies. (a) Photometric absorbance studies for determination of chromium species using pH selective approach and (b) fluorometric quenching studies for determination of chromium species using pH selective approach.

simple and there is no need to add any oxidizing agent. There are no pre-concentration methods involved, the entire study can be done at normal room temperature, no inert atmosphere required, it is bench-stable and the methods are cost-effective.

\section{Results and discussion}

\section{Proposed mechanism}

The proposed mechanism describes that chromium species complexes with activators like 1,10-phenanthroline, 2,2 -bipyridyl resulting in the formation of organo-metallic

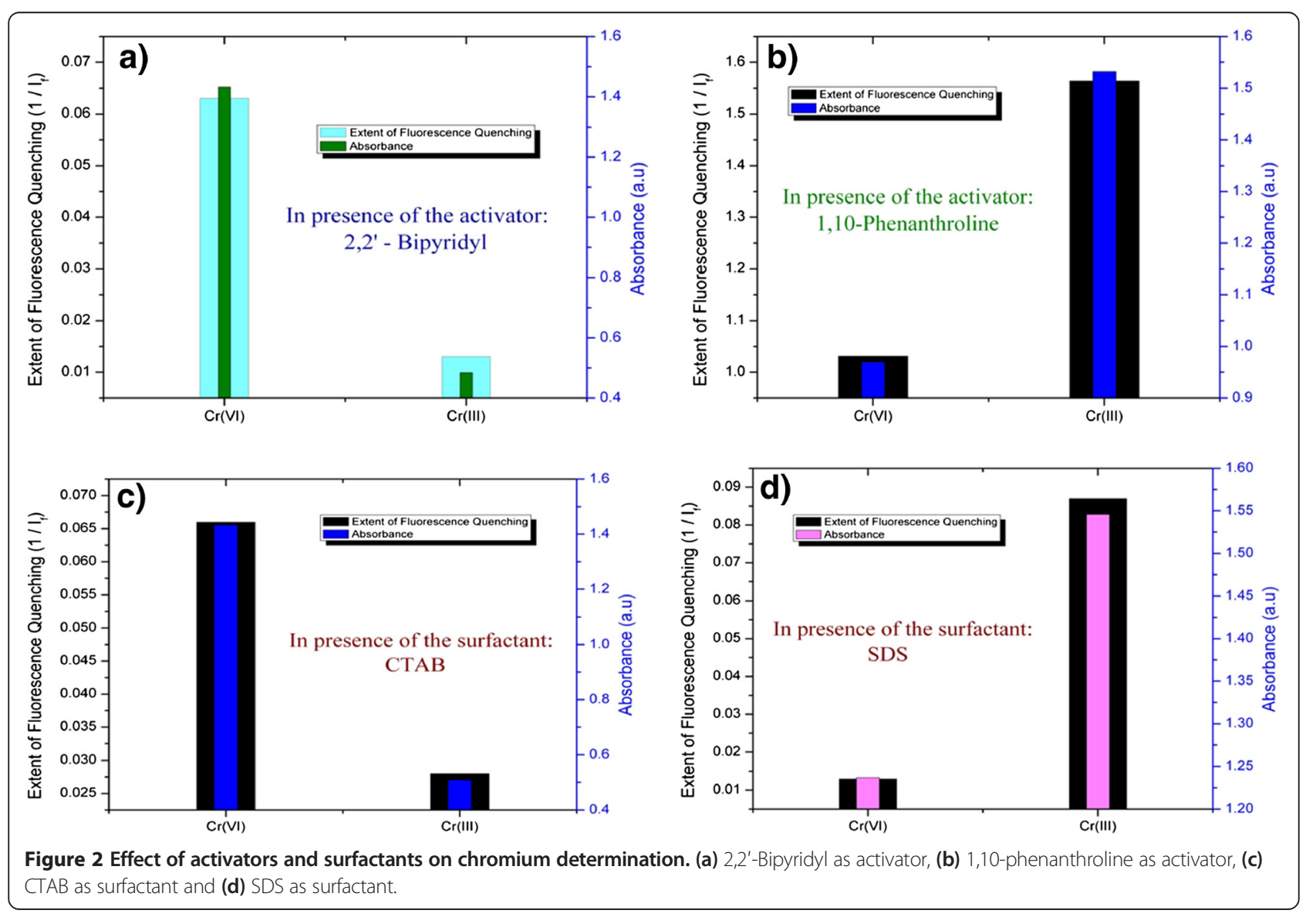


complexes. These complexes reacts with atmospheric oxygen to form highly reactive oxo-complexes, which are also unstable and short lived. This reactive oxo species attains high oxidation states which are unstable and in order to get back to their stable states from the highly unstable ones, they would accept the electrons from the HPTU. This process enables the conversion of HPTU to its disulphide. In this way, the catalytic action of chromium species in the presence of activators and surfactants was proposed (Scheme 1).

\section{Experimental observations}

The speciative determination of chromium(III) and chromium(VI) was done using photometric and fluorometric methods. In both developed methods, three parameters were proposed, which can selectively determine each species. The three parameters are the following: $\mathrm{pH}$, activator and surfactant. HPTU was used as a chromogenic reagent to selectively sense a specific species at a defined $\mathrm{pH}$. With respect to the observations pertaining to $\mathrm{pH}$ study, it was noticed that HPTU reaction was catalysed by chromium(III) ions only in the $\mathrm{pH}$ range of 3.5 to 4.2 . Similarly, chromium(VI) ions catalyse HPTU reaction only in the $\mathrm{pH}$ range of 7.8 to 8.4 . Thus, by selectively maintaining the respective $\mathrm{pH}$ ranges, one can easily and selectively determine the chromium species (Figure 1). The next parameter that was utilized in the determination was the usage of activators like pyridine, 2-aminopyridine, 2,2'-bipyridyl,

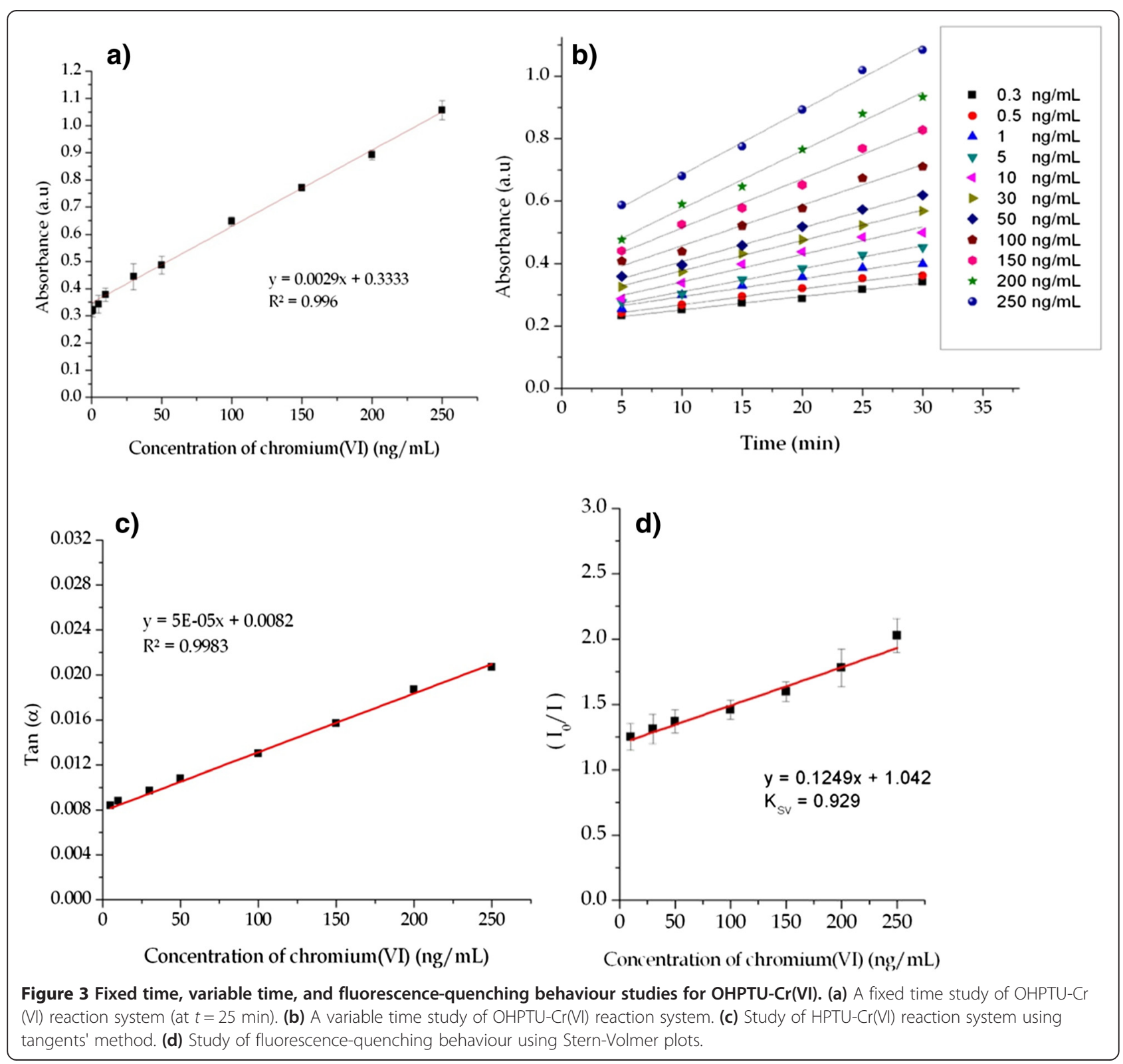




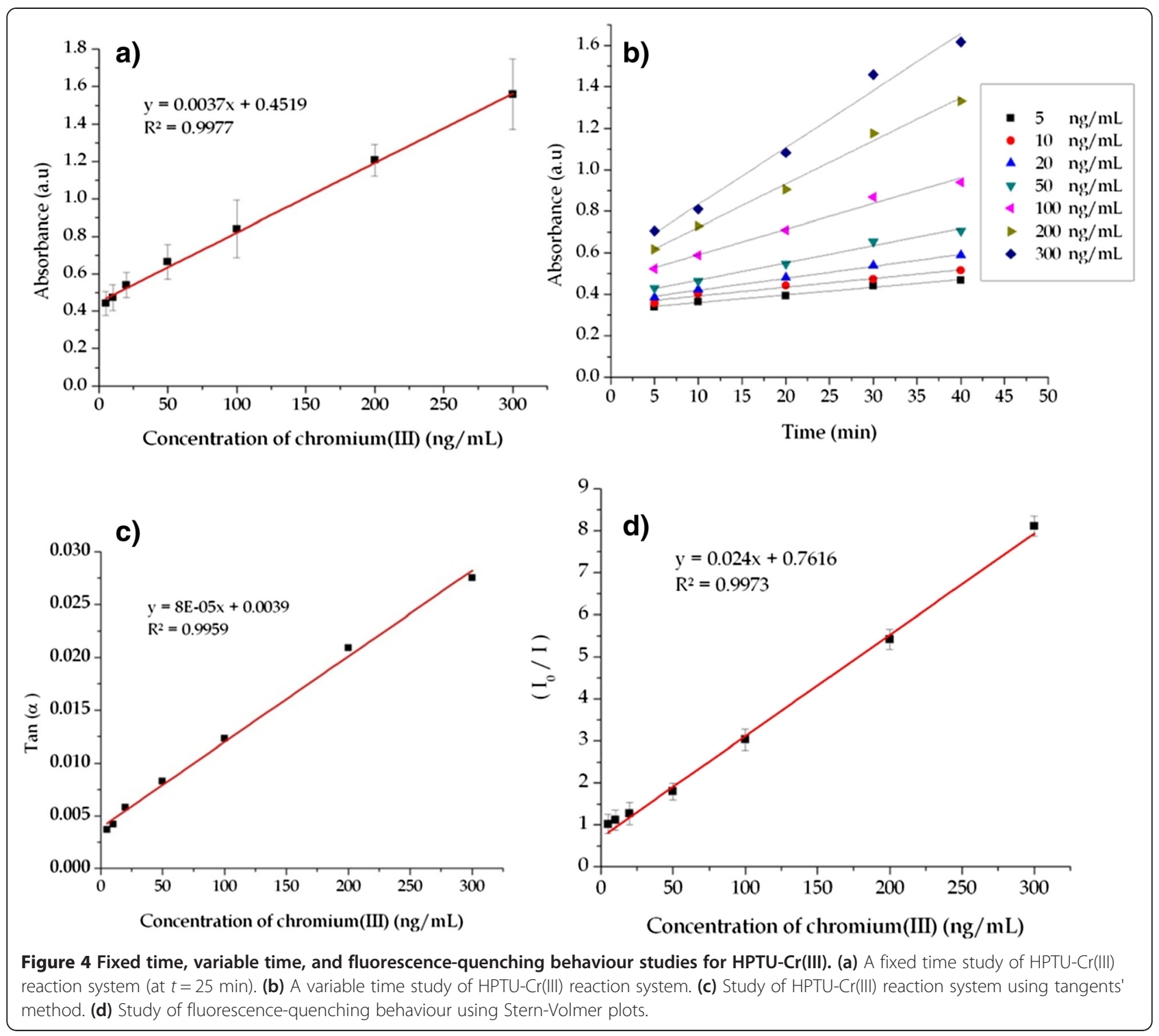

1,10-phenanthroline, etc. In the case of chromium(III), 1,10-phenanthroline acts as a very good activator, by selectively activating chromium(III) in the acidic $\mathrm{pH}$ range. Similarly, 2,2'-bipyridyl selectively activates chromium(VI) in the basic $\mathrm{pH}$ range. Thus, by the selective activation of HPTU reaction using $\mathrm{Cr}(\mathrm{III})$ - 1,10-phenanthroline and $\mathrm{Cr}(\mathrm{VI})$ - 2,2'-bipyridyl in acidic and basic $\mathrm{pH}$ ranges, the chromium species can be determined (Figure 2a,b).
The third parameter that was followed is the selective use of surfactants in addition to activators. In this study, it was observed that the anionic surfactant, sodium dodecyl sulfate (SDS) encapsules the Cr(III) - 1,10-phenanthroline moiety and acts as a micro reaction centre facilitating the oxidation of HPTU. Similar in the other case, the cationic surfactant, CTAB encapsules the $\mathrm{Cr}(\mathrm{VI})$ - 2,2'-bipyridyl moiety in basic $\mathrm{pH}$ forming a micro reaction centre and

Table 1 Determination of chromium (III) species using the proposed and standard AAS methods

\begin{tabular}{lllll}
\hline Sample & $\begin{array}{l}\text { Amount } \text { of } \mathbf{C r} \text { (III) } \\
\text { added }(\mathbf{n g})\end{array}$ & \multicolumn{3}{l}{ Experimental values for $\mathbf{C r}$ (III) $(\mathbf{n g})(\boldsymbol{n}=\mathbf{3})$} \\
\cline { 3 - 5 } & 150.0 & Photometric & Fluorometric & \\
\hline Tap water & 130.0 & $149.7 \pm 0.04$ & $149.4 \pm 0.06$ & AAS \\
Rain water & 100.0 & $132.8 \pm 0.08$ & $132.5 \pm 0.07$ & $149.6 \pm 0.06$ \\
Drainage water & $108.6 \pm 0.04$ & $108.9 \pm 0.05$ & $132.3 \pm 0.05$ \\
\hline
\end{tabular}


Table 2 Determination of chromium (VI) species using proposed and standard AAS methods

\begin{tabular}{lllll}
\hline Sample & \multicolumn{2}{l}{$\begin{array}{l}\text { Amount } \text { of } \mathbf{C r}(\mathbf{V I}) \\
\text { added }(\mathbf{n g})\end{array}$} & \multicolumn{3}{l}{ Experimental values for $\mathbf{C r}(\mathbf{V I})(\mathbf{n g})(\mathbf{n}=\mathbf{3})$} \\
\cline { 3 - 5 } & 180.0 & Photometric & Fluorometric & AAS \\
\hline Tap water & 140.0 & $179.4 \pm 0.05$ & $179.6 \pm 0.08$ & $179.5 \pm 0.07$ \\
Rain water & 120.0 & $166.8 \pm 0.08$ & $166.5 \pm 0.04$ & $163.7 \pm 0.05$ \\
Drainage water & & $138.4 \pm 0.04$ & $138.8 \pm 0.05$ & $138.5 \pm 0.07$ \\
\hline
\end{tabular}

facilitates the catalytic reaction (Figure 2c,d). Using the above parameters, the chromium species were determined selectively in the range of 0.3 to $250 \mathrm{ng} / \mathrm{mL}$. Linear plots were obtained in the absorbance study by following fixed time and tangents' methods. Similarly, fluorescence studies also inferred the quantitative linear relationship through Stern-Volmer plots (Figures 3d and 4d).

\section{Interference by foreign ions}

In the speciative determination of chromium, the effect of associated metal ions and anions was studied. It was observed that metal ions like $\mathrm{Na}(\mathrm{I}), \mathrm{Ba}(\mathrm{II}), \mathrm{Bi}(\mathrm{III}), \mathrm{Sb}(\mathrm{III})$, $\mathrm{V}(\mathrm{V}), \mathrm{W}(\mathrm{VI}), \mathrm{Ru}(\mathrm{III})$ and $\mathrm{Re}(\mathrm{II})$ showed no interference even up to 1,500-folds. Other metal ions like $\mathrm{Mn}(\mathrm{II}), \mathrm{Co}(\mathrm{II})$, $\mathrm{As}(\mathrm{V}), \mathrm{Pb}(\mathrm{II}), \mathrm{Hg}(\mathrm{II}), \mathrm{Cd}(\mathrm{II}), \mathrm{Zn}(\mathrm{II}), \mathrm{Pd}(\mathrm{II}), \mathrm{Ni}(\mathrm{II}), \mathrm{Zn}(\mathrm{II})$, $\mathrm{Ca}(\mathrm{II}), \mathrm{Mg}(\mathrm{II}), \mathrm{Zr}$ (IV), $\mathrm{Rh}(\mathrm{III}), \mathrm{Os}(\mathrm{IV}), \mathrm{Au}(\mathrm{III}), \mathrm{Mo}(\mathrm{IV})$, $\mathrm{Al}(\mathrm{III}), \operatorname{Ir}(\mathrm{III}), \mathrm{Pt}(\mathrm{II})$ and $\mathrm{Ag}(\mathrm{I})$ do not interfere up to 800 -folds at the $\mathrm{pH}$ of 8.0. $\mathrm{Fe}$ (II) and $\mathrm{Cu}$ (II) interfere up to 20 -folds, which can be masked by the addition of tartarate and thiosulphate, respectively.

\section{Analytical application of the method}

The developed methods were applied to water samples like drainage water, tap water and rain water. It was found that the concentration of chromium(VI) was comparatively more in the case of rain water and drainage water. This can be attributed to the leaching of chromium from paints, pipelines and other sources of pollution. The proposed photometric and fluorometric methods are in agreement with the experimental data obtained from standard atomic absorption spectrometry (AAS) method (Tables 1 and 2).

The obtained results of water sample analysis using absorbance and emission studies have been statistically treated using ANOVA (Tables 3 and 4). A high degree of linear relationship between both methods is very much evident from the Pearson correlation values closer

Table 3 Statistical analysis of the obtained data for chromium (III) species

\begin{tabular}{ll}
\hline Statistical parameter & Calculated value \\
\hline$F_{\text {Crit }}$ & 5.14 \\
$F_{\text {Ratio }}$ & $2.39 \mathrm{E}-05$ \\
$p$-value & 0.999 \\
\hline
\end{tabular}

to 0.999 . The $F_{\text {Ratio }}$ value calculated from ANOVA: single factor is lesser than 1 and $F_{\text {Ratio }}$ is lesser than $F_{\text {Crit }}$, in both the experiments, inferring no significant difference between the three pertained methods. Also, the analysis shows that the type of sample chosen has no significant effect on the developed methods.

\section{Experimental}

\section{Chemicals and instrumentation}

Analytical grade chemicals with high purity purchased from Sigma-Aldrich Chemicals Ltd., Bengaluru, India, were used in the investigation. Similarly, HPLC-graded solvents purchased from Merck, Mumbai, Maharashtra, India, were used appropriately. The standard prescribed procedure was employed for the preparation of buffer solutions (Vogel 1961). The $\mathrm{pH}$ adjustments were appropriately done using Micropro pH meter (Techno Instruments Co., Bangalore, India). The instruments such as PerkinElmer LS-55 fluorimeter (PerkinElmer, Waltham, MA, USA) and Hitachi-2001 spectrophotometer (Hitachi Ltd, Chiyoda-ku, Japan) were utilized for experimental studies. Mettler Toledo AB204-S (Mettler-Toledo, LLC, Columbus, OH, USA) was utilized for weighing purposes.

\section{Reagents}

In an 'A' grade 100-mL volumetric flask, $100.0361 \mathrm{mg}$ of chromium (III) chloride was dissolved thoroughly and the resultant solution was standardised with EDTA. A stock solution of $6.3 \mathrm{mM}(1.0 \mathrm{mg} / \mathrm{mL})$ of chromium (III) was obtained.

In a 100-mL volumetric flask, $100.0704 \mathrm{mg}$ of potassium dichromate was weighed, and deionised water was added up to the mark. The prepared solution was standardised by titrating with Mohr's salt, using diphenylamine as an indicator along with $2.0 \mathrm{~mL}$ of $1: 1 \mathrm{H}_{3} \mathrm{PO}_{4}$. A stock solution of $3.4 \mathrm{mM}(1.0 \mathrm{mg} / \mathrm{mL})$ of chromium (VI) was obtained.

Table 4 Statistical analysis of the obtained data for chromium (VI) species

\begin{tabular}{ll}
\hline Statistical parameter & Calculated value \\
\hline$F_{\text {Crit }}$ & 5.14 \\
$F_{\text {Ratio }}$ & 0.0023 \\
$p$-value & 0.997 \\
\hline
\end{tabular}


$1.0407 \mathrm{~g}$ of 1,10-phenanthroline was weighed and dissolved in ethanol in a $100-\mathrm{mL}$ volumetric flask to get $0.58 \mathrm{mM}$ of 1,10-phenanthroline reagent.

By weighing $1.0207 \mathrm{~g}$ of 2,2 '-bipyridyl in a $100-\mathrm{mL}$ volumetric flask, $0.66 \mathrm{mM}$ of 2,2'-bipyridyl reagent was prepared, and ethanol was added up to the mark.

In distilled water using a $100-\mathrm{mL}$ volumetric flask to get a 1\% SDS solution, $1.0 \mathrm{~g}$ of SDS was weighed and dissolved. In a $100-\mathrm{mL}$ volumetric flask, $1.0 \mathrm{~g}$ of CTAB was weighed and dissolved in distilled water to get $1 \%$ CTAB solution.

The above recommended experimental procedures were followed as described (Vogel 1961).

\section{Methods}

The reagent, HPTU, was synthesized (Sunil and Rao 2012a) and the analytical parameters, and their influence was studied systematically. A solution of $1.0 \mathrm{~mL}$ of acetate buffer of $\mathrm{pH}=4.0$ and appropriate amount ( 5 to $300 \mathrm{ng} / \mathrm{mL}$ ) of chromium (III) solution was pipetted in to a $10.0-\mathrm{mL}$ volumetric flask, followed by $1.0 \mathrm{~mL}$ of 1,10-phenanthroline and $1.0 \mathrm{~mL}$ of $1 \%$ SDS. The temperature was maintained at $25^{\circ} \mathrm{C}$. Two milliliters of HPTU $(1 \mathrm{mg} / \mathrm{mL})$ solution was then added, and millipore water was added up to the mark. The resulting reaction mixture was transferred into $10-\mathrm{mm}$ quartz cuvettes. The photometric measurements were recorded at $\lambda_{\mathrm{Max}}=416 \mathrm{~nm}$. The fluorescence emission measurements were recorded at $\lambda_{\mathrm{Em}}=520 \mathrm{~nm}$ upon excitation at $\lambda_{\mathrm{Ex}}=416 \mathrm{~nm}$, respectively, at $30 \mathrm{~min}$. The blank experiments were repeated by following the same procedure to obtain relative fluorescence intensity $I_{0}$ and the value of $I_{0} / I$ was calculated. The calibration graph was plotted and the method was applied for the determination of chromium in waste water and plant samples. Water samples were boiled, treated with concentrated nitric acid and then filtered to remove organic particulate matter before using for the analysis. The digestion for plant sample was done as mentioned (Sunil and Rao 2012b). The same procedure was followed by taking chromium (VI) solution. Here, $2,2^{\prime}$-bipyridyl was used as an activator and $1 \% \mathrm{CTAB}$ as a surfactant.

\section{Conclusions}

The results suggest that the speciative determination of chromium species was achieved by the selective application of parameters of $\mathrm{pH}$, activators and surfactants using photometric and fluorometric techniques. Chromium(III) was determined in the $\mathrm{pH}$ range of 3.5 to 4.2 and in presence of 1,10-phenanthroline as an activator and SDS as a surfactant. Chromium(VI) was determined in the $\mathrm{pH}$ range of 7.8 to 8.4 and in presence of $2,2^{\prime}$-bipyridyl as an activator and CTAB as a surfactant. The methods are fairly sensitive with a determination range of 0.3 to
$250 \mathrm{ng} / \mathrm{mL}$. The proposed methods were applied to tap water, rain water and drainage water with satisfactory results.

\section{Competing interests}

The authors declare no competing interests.

\section{Authors' contributions}

Sunil has performed the entire experimental, analytical work and prepared the draft of the manuscript. The supervision of this work was done by Rao. All authors read and approved the final manuscript.

\section{Acknowledgements}

Authors are thankful to the Founder Chancellor, Bhagawan Sri Sathya Sai Baba and the authorities of Sri Sathya Sai Institute of Higher Learning for the support and guidance.

Received: 23 January 2014 Accepted: 6 January 2015

Published online: 25 February 2015

\section{References}

Arancibia V, Nagles E, Gomez M, Rojas C (2012) Speciation of Cr (VI) and Cr (III) in water samples by adsorptive stripping voltammetry in the presence of pyrogallol red applying a selective accumulation potential. Int J Electrochem Sci 7:11444-11455

Duran A, Tuzen M, Soylak M (2009) Preconcentration of some trace elements via using multiwalled carbon nanotubes as solid phase extraction adsorbent. J Haz Mat 169:466-471

El-Shahawi MS, Al-Saidi HM, Bashammakh AS, Al-Sibaai AA, Abdelfadeel MA (2011) Spectrofluorometric determination and chemical speciation of trace concentrations of chromium (III and VI) species in water using the ion pairing reagent tetraphenyl-phosphonium bromide. Talanta 84:175-179

Ezoddin M, Shemirani F, Khani R (2010) Application of mixed-micelle cloud point extraction for speciation analysis of chromium in water samples by electrothermal atomic absorption spectrometry. Desalination 262:183-187

Gomez V, Callao MP (2006) Chromium determination and speciation since 2000 TrAC Trend Anal Chem 25:1006-1015

Grabarczyk M, Tyszczuk K, Korolczuk M (2006) Catalytic adsorptive stripping voltammetric procedure for determination of total chromium in environmental materials. Electroanalysis 18:1223-1226

Guerrero ML, Alonso EV, Pavon JC, Cordero MS, De Torres AG (2012) On-line preconcentration using chelating and ion-exchange minicolumns for the speciation of chromium (III) and chromium (VI) and their quantitative determination in natural waters by inductively coupled plasma mass spectrometry. J Anal At Spectrom 27:682-688

Hashemi M, Daryanavard SM (2012) Ultrasound-assisted cloud point extraction for speciation and indirect spectrophotometric determination of chromium (III) and (VI) in water samples. Spectrochim Acta Mol Biomol Spectros 92:189-193

Hosseini MS, Belador F (2009) Cr (III)/Cr (VI) speciation determination of chromium in water samples by luminescence quenching of quercetin. J Haz Mat 165:1062-1067

Hotta H, Yata K, Kamarudin KFB, Kurihara S, Tsunoda KI, Fukumoto N, Kinugasa SI (2012) Determination of chromium (III), chromium (VI) and total chromium in chromate and trivalent chromium conversion coatings by electrospray ionization mass spectrometry. Talanta 88:533-536

Karosi R, Andruch V, Posta J, Balogh J (2006) Separation of chromium (VI) using complexation and its determination with GFAAS. Microchem J 82:61-65

Kiran K, Kumar KS, Prasad B, Suvardhan K, Lekkala RB, Janardhanam K (2008) Speciation determination of chromium (III) and (VI) using preconcentration cloud point extraction with flame atomic absorption spectrometry (FAAS). J Haz Mat 150:582-586

Kotas J, Stasicka Z (2000) Chromium occurrence in the environment and methods of its speciation. Environ Pollut 107:263-283

Martone N, Rahman GM, Pamuku M, Kingston HS (2013) Determination of chromium species in dietary supplements using speciated isotope dilution mass spectrometry with mass balance. J Agr Food Chem 61:9966-9976

Moghadam MR, Dadfarnia S, Haji Shabani AM (2011) Speciation and determination of ultra trace amounts of chromium by solidified floating organic drop microextraction (SFODME) and graphite furnace atomic absorption spectrometry. J Haz Mat 186:169-174

Padarauskas A, Naujalis E (1998) On-line preconcentration and determination of chromium (VI) in waters by high-performance liquid chromatography using 
pre-column complexation with 1,5-diphenylcarbazide. J Chromatogr A 808:193-199

Parmar P, Pillai AK, Gupta VK (2010) An improved colorimetric determination of micro amounts of chromium (VI) and chromium (III) using p-aminoacetophenone and phloroglucinol in different samples. J Anal Chem 65:582-587

Ren Y, Fan Z, Wang J (2007) Speciation analysis of chromium in natural water samples by electrothermal atomic absorbance spectrometry after separation/ preconcentration with nanometer-sized zirconium oxide immobilized on silica gel. Microchim Acta 158:227-231

Sánchez-Moreno RA, Gismera MJ, Sevilla MT, Procopio JR (2010) Direct and rapid determination of ultratrace heavy metals in solid plant materials by ET-AAS ultrasonic-assisted slurry sampling. Phytochem Anal 21:340-347

Schramel P, Xu LQ, Knapp G, Michaelis M (1992) Application of an on-line preconcentration system in simultaneous ICP-AES. Microchim Acta 106:191-201

Soomro R, Ahmed MJ, Memon N (2011) Simple and rapid spectrophotometric determination of trace level chromium using bis (salicylaldehyde) orthophenylenediamine in nonionic micellar media. Turk J Chem 35:155-170

Sun YC, Lin CY, Wu SF, Chung YT (2006) Evaluation of on-line desalter-inductively coupled plasma-mass spectrometry system for determination of $\mathrm{Cr}$ (III), $\mathrm{Cr}(\mathrm{VI})$, and total chromium concentrations in natural water and urine samples. Spectrochim Acta B 61:230-234

Sunil A, Rao SJ (2012a) Eco-friendly approach for a facile synthesis of o-hydroxyphenylthiourea and its property as an analytical reagent in sensing mercury (II). Res J Chem Sci 2:30-40

Sunil A, Rao SJ (2012b) Surfactant based fluorometric sensing of copper at picogram level using o-hydroxyphenylthiourea with pyridine as activator. Int J Chem Anal Sci 3:1318-1321

Sunil A, Rao SJ (2015) Photometric and fluorimetric determination of chromium (VI) using metal-oxo mediated reaction of 1-(2-hydroxyphenyl)thiourea in micellar medium. J Anal Chem 70:159-165

Themelis DG, Kika FS, Economou A (2006) Flow injection direct spectrophotometric assay for the speciation of trace chromium (III) and chromium (VI) using chromotropic acid as chromogenic reagent. Talanta 69:615-620

Vogel Al (1961) A text book of quantitative inorganic analysis. Longman Group Limited, London

Wang LL, Wang JQ, Zheng ZX, Xiao P (2010) Cloud point extraction combined with high-performance liquid chromatography for speciation of chromium (III) and chromium (VI) in environmental sediment samples. J Haz Mat 177:114-118

Wu Y, Jiang Y, Han D, Wang F, Zhu J (2007) Speciation of chromium in water using crosslinked chitosan-bound FeC nanoparticles as solid-phase extractant, and determination by flame atomic absorption spectrometry. Microchim Acta 159:333-339

Yildiz Z, Arslan G, Tor A (2011) Preconcentrative separation of chromium (III) species from chromium ( $\mathrm{VI}$ ) by cloud point extraction and determination by flame atomic absorption spectrometry. Microchim Acta 174:399-405

Zeng C, Lin Y, Zhou N, Zheng J, Zhang W (2012) Room temperature ionic liquids enhanced the speciation of $\mathrm{Cr}(\mathrm{VI})$ and $\mathrm{Cr}$ (III) by hollow fiber liquid phase microextraction combined with flame atomic absorption spectrometry. J Haz Mat 237:365-370

\section{Submit your manuscript to a SpringerOpen ${ }^{\circ}$ journal and benefit from:}

- Convenient online submission

- Rigorous peer review

- Immediate publication on acceptance

- Open access: articles freely available online

- High visibility within the field

- Retaining the copyright to your article

Submit your next manuscript at $>$ springeropen.com 